\title{
Aktivitas Antibakteri Nanoemulsi Minyak Lengkuas (Alpinia galanga L. Willd) dalam Menghambat Pertumbuhan Helicobacter pylori
}

\author{
Yulianto Ade Prasetya ${ }^{1)^{*}}$, Khoirun Nisyak ${ }^{1)}$, Eviomitta Rizki Amanda ${ }^{1)}$ \\ ${ }^{1)}$ Program Studi Diploma III Teknologi Laboratorium Medis, Sekolah Tinggi Ilmu Kesehatan (STIKES) Rumah Sakit \\ Anwar Medika, Jalan Raya By Pass Krian Km.33 Sidoarjo, Jawa Timur, Indonesia \\ *)Alamat korespondensi: yuliantoadeprasetya@gmail.com
}

\begin{abstract}
ABSTRAK
Helicobacter pylori termasuk bakteri patogen oportunistik yang berkolonisasi di lambung dan mampu memicu terjadinya peradangan lokal. Infeksi bakteri ini apabila tidak segera diobati dapat berkembang menjadi penyakit yang lebih serius seperti gastritis atrofi, metaplasia usus, dan noncardia gastric adenocarcinoma. Penelitian ini bertujuan untuk mengetahui aktivitas nanoemulsi minyak lengkuas (Alpinia galanga $\mathrm{L}$. Willd) dalam menghambat pertumbuhan bakteri $\boldsymbol{H}$. pylori. Nanoemulsi minyak lengkuas dibuat dengan mencampurkan fase air sedikit demi sedikit ke dalam fase minyak dan surfaktan dengan bantuan magnetic stirrer dan ultrasonikator. Karakterisasi nanoemulsi minyak lengkuas dilakukan dengan alat Particle Size Analyzer (PSA) untuk mengetahui ukuran droplet yang terbentuk dan spektrofotometer UV-Vis pada panjang gelombang $630 \mathrm{~nm}$ untuk mengetahui persentase transmitan. Uji aktivitas antibakteri nanoemulsi minyak lengkuas terhadap $H$. pylori dilakukan dengan metode difusi sumuran. Hasil penelitian menunjukkan bahwa nanoemulsi minyak lengkuas mampu menghambat pertumbuhan bakteri $\boldsymbol{H}$. Pylori. Pada konsentrasi yang paling rendah (kadar hambat minimum=KHM) yaitu 1\% (ukuran droplet 19,9 nm) memiliki zona penghambatan sebesar $9,5 \mathrm{~mm}$. Nanoemulsi minyak lengkuas dapat digunakan sebagai kandidat pengobatan infeksi lambung yang disebabkan oleh $\boldsymbol{H}$. pylori.
\end{abstract}

Kata kunci: Bakteri, Helicobacter pylori, minyak atsiri, nanoemulsi, nanoteknologi

\section{Antibacterial Activity of Galangal (Alpinia galanga L. Willd) Oil Nanoemulsion in Inhibiting the Growth of Helicobacter pylori}

\author{
Yulianto Ade Prasetya ${ }^{1)^{*}}$, Khoirun Nisyak ${ }^{1)}$, Eviomitta Rizki Amanda ${ }^{1)}$ \\ ${ }^{1)}$ Diploma III Medical Laboratory Technology, Sekolah Tinggi Ilmu Kesehatan (STIKES) Anwar Medika Hospital, Jalan \\ Raya By Pass Krian Km.33 Sidoarjo, East Java, Indonesia \\ *)Email: yuliantoadeprasetya @ gmail.com
}

\begin{abstract}
Helicobacter pylori is an opportunistic pathogenic bacterium that colonizes the stomach and provokes a local inflammation. This bacterial infection is expected to develop into more serious diseases such as atrophic gastritis, intestinal metaplasia, and noncardia gastric adenocarcinoma. This research aimed to study the activity of galangal (Alpinia galanga $\mathrm{L}$. Willd) oil nanoemulsion in inhibiting the growth of $\boldsymbol{H}$. pylori. Galangal oil nanoemulsion was made by mixing the air phase into the oil phase and surfactant with magnetic stirrer and ultrasonicator. Characterization of galangal oil nanoemulsion was performed with a Particle Size Analyzer (PSA) to determine the size of the droplets formed and UV-Vis spectrophotometer at a wavelength of $630 \mathrm{~nm}$ to look for the transmittance results. The galangal oil nanoemulsion antibacterial activity test against $H$. pylori was carried out using the well-diffusion method. The results showed that galangal oil nanoemulsion was able to inhibit the growth of $H$. pylori bacteria. The lowest concentration (minimum inhibitory concentraton=MIC) of $1 \%$ (droplet size $19.9 \mathrm{~nm}$ ) had an inhibition zone by $9.5 \mathrm{~mm}$. Galangal oil nanoemulsion can be used as a candidate for the treatment of gastric infections caused by $\boldsymbol{H}$. pylori.
\end{abstract}

Keywords: Bacteria, essential oil, Helicobacter pylori, nanoemulsion, nanotechnology 


\section{PENDAHULUAN}

Helicobacter pylori merupakan bakteri Gram negatif berbentuk spiral, memiliki flagel lopotrikus, mampu berkolonisasi pada lambung dan memicu terjadinya peradangan lokal. Infeksi lambung yang disebabkan oleh H. pylori apabila tidak segera diobati dapat menjadi penyakit yang lebih serius seperti gastritis atrofi, metaplasia usus, dan noncardia gastric adenocarcinoma [1]. Hampir 50\% penduduk di dunia terinfeksi $H$. pylori [2] dan infeksi ini menjadi semakin tinggi pada negara belum berkembang $(93,6 \%)$ dibandingkan negara berkembang $(15,5 \%)$ [3]. Hal ini dikaitkan dengan berbagai faktor seperti umur, status sosial ekonomi, sanitasi, kepadatan tempat tinggal, merokok, penggunaan obat antiinflamasi nonsteroid, golongan darah $\mathrm{O}$, berat badan dan riwayat keluarga yang terjangkit tukak lambung yang dapat mentrasmisikan bakteri $H$. pylori [1]. Prevalensi kanker lambung di Indonesia tercatat sebanyak 2,8/100.000 kasus [4]. Pengobatan untuk infeksi ini sangat sulit karena membutuhkan terapi kombinasi sedikitnya dua antibiotik dikarenakan adanya multidrug resistance [5]. Pencarian alternatif pengobatan terbaru berupa zat aktif dari tumbuhan mulai banyak dikembangkan karena lebih efektif, murah, mudah dalam penggunaan, aman, toksisitas rendah, dan mampu mencegah penyebaran gen resistensi antarspesies mikroorganisme [5].

Minyak atsiri merupakan salah satu zat aktif dari tumbuhan yang terbukti efektif melawan berbagai macam mikrooganisme. Minyak atsiri lengkuas (Alpinia galanga [L]. Willd.) terbukti sebagai antimikroba, antijamur, dan antiamoeba [7], yang mengandung metil-sinamat $48 \%$, sineol $20 \%$ $30 \%$, eugenol, kamfer $1 \%$, seskuiterpen, $\delta$ pinen, galangin, galangol, dan beberapa senyawa flavonoid [8]. Penelitian Yuharmen $e t$ al. [9] menunjukkan adanya aktivitas penghambatan pertumbuhan Escherichia coli dan Staphylococcus aureus oleh minyak lengkuas. Penelitian Khoerrunisa [8] juga membuktikan bahwa rimpang lengkuas memiliki sifat sebagai antibakteri terhadap Staphylococcus aureus, Micrococcus luteus, dan Bacillis cereus dengan metode disk diffusion test, namun pemanfaatannya dalam menghambat atau membunuh $H$. pylori belum pernah dilaporkan sebelumnya. Bakteri ini cukup sulit untuk diobati karena sifatnya yang tahan asam, mampu berpenetrasi ke mukosa lambung manusia, dan resisten terhadap berbagai macam antibiotik, maka diperlukan teknologi baru dengan pendekatan nanoteknologi. Minyak lengkuas pada penelitian ini dibuat dalam ukuran nano droplet, yaitu ukuran 20-100 $\mathrm{nm}$ dan diharapkan mampu berpenetrasi dalam membran bakteri. Nanopartikel memiliki luas permukaan yang tinggi dan reaktivitasnya spesifik sehingga sesuai untuk bahan obat dalam berbagai dosis serta meningkatkan regulasi sistem penghantaran obat dalam tubuh [10]. Beberapa penelitian menunjukkan bahwa minyak atsiri yang dibuat dalam bentuk nanoemulsi mampu meningkatkan kemampuannya sebagai antibakteri seperti pada nanoemulsi dari Cymbopogon flexuosus sebagai antimikroba terhadap Mycobacterium foruitum, M. massiliense, dan M. abscessus [11] dan nanoemulsi minyak Eucalyptus globulus mampu menghambat pertumbuhan Candida albicans, $C$. tropicalis dan $C$. glabrata [12]. Berdasarkan latar belakang tersebut, penelitian ini bertujuan untuk membuat nanoemulsi dari minyak lengkuas untuk menghambat pertumbuhan $H$. pylori. Pembuatan nanoemulsi dilakukan dengan mencampurkan fase air sedikit demi sedikit ke dalam fase minyak dan surfaktan dengan bantuan magnetic stirrer dan ultrasonikator. Karakterisasi nanoemulsi minyak lengkuas dilakukan dengan alat Particle Size Analyzer (PSA) untuk mengetahui ukuran droplet yang terbentuk dan spektrofotometer UV-Vis pada panjang gelombang $630 \mathrm{~nm}$ untuk mengetahui persentase transmitan. Aktivitas nanoemulsi minyak lengkuas dilakukan dengan menentukan kadar hambat minimum (KHM) yang dilakukan dengan teknik difusi sumur.

\section{METODE PENELITIAN}

Sampel minyak atsiri lengkuas (Alpinia galanga (L.) Willd). Minyak atsiri lengkuas (Alpinia galanga (L.) Willd) dibeli di CV. Nusaroma Jakarta dan dikarakterisasi senyawa yang terkandung di dalamnya menggunakan Gas Chomatography-Mass Spectrometry (GCMS) di Laboratorium Instrumentasi Jurusan Kimia Universitas Brawijaya Malang.

Kultur Helicobcater pylori. Helicobacter pylori yang digunakan berasal dari Laboratorium Mikrobiologi Fakultas MIPA 
Universitas Brawijaya Malang. Bakteri ditumbuhkan dalam media Brucella Broth dengan penambahan darah domba $5 \%$ dan diinkubasi suhu $35^{\circ} \mathrm{C}$ dengan kadar $\mathrm{CO}_{2} 10 \%$ selama 48 jam.

Pembuatan nanoemulsi minyak lengkuas (Alpinia galanga L. Willd). Prosedur pembuatan nanoemulsi minyak lengkuas mengacu pada Quatrin et al. [12] dengan modifikasi. Fase minyak dibuat sebanyak 5 $\mathrm{mL}$ dengan konsentrasi minyak lengkuas yang digunakan adalah $1 \%, 2 \%, 3 \%, 4 \%$, dan $5 \%$ kemudian diaduk dengan magnetic stirrer selama sepuluh menit. Sebanyak $5 \mathrm{~mL}$ Tween 80 sebagai surfaktan dimasukkan sedikit demi sedikit sambil dilakukan pengandukan menggunakan magnetic stirrer dengan kecepatan $1000 \mathrm{rpm}$ selama 15 menit. Fase air ditambahkan hingga mencapai volume air nanoemulsi yaitu $20 \mathrm{ml}$ dan dimasukkan sedikit demi sedikit sambil dilakukan pengadukan dengan magnetic stirerr dengan kecepatan 1500 rpm selama 15 menit. Nanoemulsi minyak lengkuas kemudian dimasukkan dalam ultrasonikator dengan frekuensi $50 \mathrm{KHz}$ selama 45 menit pada suhu ruang. Hasil visual nanoemulsi minyak lengkuas yang diharapkan yaitu terlihat jernih dan transparan.

Karakterisasi nanoemulsi minyak lengkuas. Nanoemulsi minyak lengkuas yang telah dibuat kemudian dikarakterisasi meliputi ukuran droplet dan kejernihan. Penentuan ukuran droplet menggunakan Particle Size Analyzer (PSA) di Pusat Penelitian Nanosains dan Nanoteknologi (PPNN) Institut Teknologi Bandung (ITB), yang membutuhkan sebanyak $15 \mathrm{~mL}$ sampel nanoemulsi minyak lengkuas untuk analisisnya. Nanoemulsi juga dilakukan analisis kejernihan menggunakan spektrofotometer UV-Vis, yaitu sebanyak 1 $\mathrm{mL}$ sampel nanoemulsi minyak lengkuas dimasukkan ke dalam kuvet kemudian persentase transmitan dibaca pada panjang gelombang $630 \mathrm{~nm}$.

Uji aktivitas antibakteri nanoemulsi minyak lengkuas terhadap $\boldsymbol{H}$. pylori. Kultur bakteri ditumbuhkan pada media Brucella Broth dengan penambahan darah domba 5\% selama 48 jam suhu $37{ }^{\circ} \mathrm{C}$ dan kadar $\mathrm{CO}_{2} 10 \%$ hingga mencapai kepadatan bakteri sebesar $10^{7}$ CFU/ml. Satu mililiter kultur uji dimasukkan ke dalam tabung reaksi yang berisi Brucella agar yang masih cair (suhu $40^{\circ} \mathrm{C}$ ) dan dihomogenasi menggunakan vortex. Kultur kemudian dimasukkan dalam cawan Petri steril dan dibiarkan hingga memadat. Media yang telah padat kemudian diberi lubang menggunakan cork borer (diameter $6 \mathrm{~mm}$ ). Nanoemulsi minyak lengkuas sebanyak $50 \mu \mathrm{L}$ kemudian dimasukkan ke dalam sumuran dan dibiarkan berdifusi selama satu jam suhu ruang. Kultur kemudian diinkubasi dalam inkubator $\mathrm{CO}_{2} 10 \%$ pada suhu $37{ }^{\circ} \mathrm{C}$ selama 48 jam. Kontrol negatif yang digunakan adalah akuades steril, sedangkan kontrol positif menggunakan antibiotik sefotaksim $30 \mu \mathrm{L}$. Zona penghambatan dihitung berdasarkan diamater zona bening yang terbentuk, dengan kriteria <9 mm nonaktif; 9-12 mm aktif parsial; 13-18 mm aktif; >18 mm sangat aktif. Pengujian ini dilakukan dilakukan sebanyak tiga ulangan.

\section{HASIL DAN PEMBAHASAN}

Identifikasi senyawa yang terkandung dalam minyak lengkuas (Alpinia galanga (L.) Willd) dapat dilihat dari puncak dan waktu retensi dari data kromatogram (Gambar 1). Puncak tertinggi yaitu nomer sembilan berupa metil sinamat dan puncak nomer enam merupakan zineol. Hasil kromatogram pada Tabel 1 menunjukkan bahwa metil sinamat memiliki persentase tertinggi sebesar 46,68\% dan diikuti oleh senyawa zineol sebesar $20,41 \%$ dan pinen $10,80 \%$.

Senyawa utama dalam minyak lengkuas adalah metil sinamat yang mudah sekali memadat menjadi granul walaupun dalam penyimpanan yang tertutup rapat, sehingga pembuatan dalam bentuk nanoemulsi untuk terapi sangat tepat untuk digunakan [13] karena cenderung lebih stabil. Methyl cinnamate merupakan senyawa turunan dari cinnamate acid. Turunan cinnamate ((5nitrofuran-2-yl)methyl-(2E)-3-phenyl-prop-2enoate, menunjukkan aktivitas penghambatan yang baik terhadap biofilm Candida albicans. Senyawa tersebut mampu menghambat pembentukan biofilm dan dapat mengurangi aktivitas metabolik dari biofilm yang sudah terbentuk sebelumnya. Selain itu, minyak lengkuas (Alpinia galanga (L.) Willd) dapat menghambat produksi enzim eksoprotease pada sistem quorum sensing Aeromonas hidrophil [15]. Metil sinamat terbukti memiliki bioaktivitas hambatan bakteri lebih baik dibandingkan turunannya seperti etil sinamat, butil sinamat, dan 2-butil sinamat dalam 
menghambat pertubuhan bakteri Escherichia coli, Bacillus subtilis, Pseudomonas aeruginosa, dan Candida albicans [16].

Zineol yang merupakan komponen tertinggi ke-2 setelah metil sinamat dalam kandungan minyak lengkuas juga terbukti mampu menghambat pertumbuhan Bacillus cereus [17]. Zineol atau 1,8 Sineol merupakan eter siklik dengan nama sistematik 1,3,3-trimethyl2-oxabicycol[2,2,2] octane yang termasuk ke dalam kelompok hidrokarbon teroksigenasi monoterpen. Senyawa ini selain sebagai antibakteri terhadap kelompok Gram positif dan negatif, juga memiliki sifat sebagai antikanker, antitumor, antifungi, antiinflamasi, dan antioksidan [18]. Minyak lengkuas memiliki mekanisme kerja sebagai antibakteri dengan cara merusak membran dalam, membran luar, dan mengakibatkan terjadinya koagulasi sitoplasma. Selain itu, komponen yang terdapat di minyak lengkuas mampu mengakibatkan perubahan $\mathrm{pH}$ internal dan denaturasi protein [19].

Pembuatan nanoemulsi dilakukan dengan mencampurkan fase organik dan fase minyak. Kedua fase dihomogenasi menggunakan sonikator untuk memecah partikel-partikel menggunakan campuran surfaktan tween 80 . Perbandingan konsentrasi antara surfaktan dan minyak lengkuas menentukan keberhasilan pembentukan nanoemulsi. Selain itu, alat yang digunakan juga berpengaruh. Untuk memecah partikel-partikel emulsi minyak dapat digunakan magnetic stirrer dan sonikator, kemudian ukuran nanoemulsi minyak dikarakterisasi menggunakan PSA. Penggunaan tween lebih efektif untuk pembuatan nanoemulsi dibandingkan dengan biopolimer lain seperti caseinat dan beta lactoglobulin [21]. Ukuran droplet yang diharapkan adalah dalam bentuk nano yaitu berkisar 20 - $100 \mathrm{~nm}$ [18]. Hasil analisis menggunakan PSA (Tabel 2) menunjukkan bahwa nanoemulsi $1 \%$ memiliki ukuran paling kecil yaitu sebesar 19,9 nm sedangkan paling besar berukuran 47,9 $\mathrm{nm}$ pada konsentrasi nanoemulsi 5\%. Hal ini menunjukkan semakin besar konsentrasi minyak lengkuas yang digunakan untuk nanoemulsi maka ukuran droplet nano yang dihasilkan semakin besar, sehingga diperlukan surfaktan yang lebih banyak dan waktu homogenisasi menggunakan stirer dan sonikasi yang lebih lama. Walaupun demikian, semua nanoemulsi yang terbentuk telah memenuhi kriteria yaitu kurang dari 100 nm. Nanoemulsi yang dihasilkan memiliki bau khas dari minyak lengkuas dan berwarna bening. Nanoemulsi yang baik memiliki \% transmitan medekati 99\% seperti air.

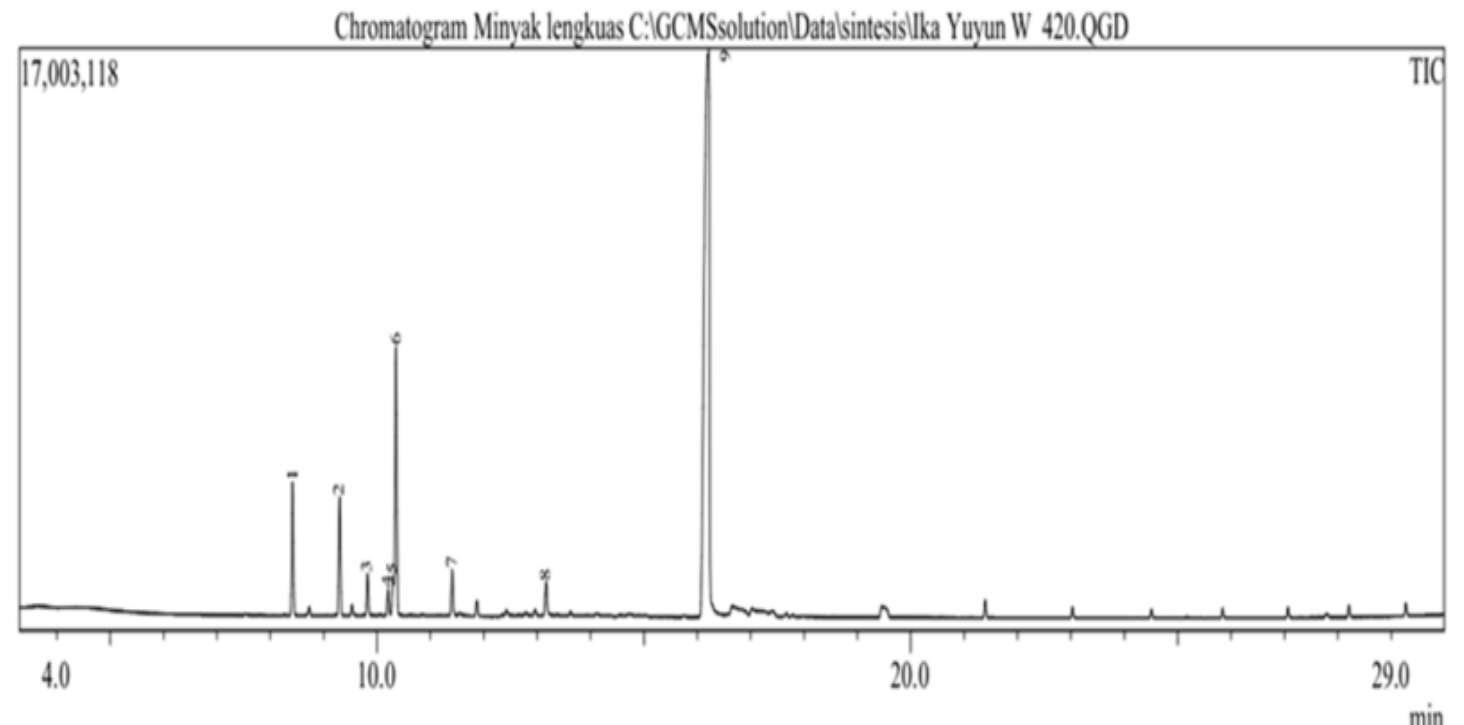

Gambar 1. Hasil kromatogram minyak lengkuas dengan GC-MS 
Tabel 1. Komponen minyak lengkuas hasil komatogram menggunakan GC-MS

\begin{tabular}{ccccc}
\hline No & $\begin{array}{c}\text { Waktu Retensi } \\
\text { (menit) }\end{array}$ & Area (\%) & Tinggi (\%) & Komponen \\
\hline 1 & 8,418 & 5,14 & 10,80 & Pinene \\
2 & 9,299 & 4,84 & 9,58 & Beta-Pinene \\
3 & 9.822 & 1,58 & 3,24 & p-metha-1.5-diena \\
4 & 10,207 & 1,01 & 2,05 & 1-Methyl-2-isopropilbenzene \\
5 & 10,300 & 0,60 & 1,24 & Limonene \\
6 & 10,356 & 9,69 & 20,41 & Zineol \\
7 & 11,409 & 1,72 & 3,43 & 1.3.3-Trymethylnorcamphor \\
8 & 13,166 & 1,47 & 2,67 & Cyclohexene-1-methyl-4-(2- \\
& 16,213 & 73,94 & 46,48 & propanol) \\
9 & & & & Cinnamic Acid \\
\hline
\end{tabular}

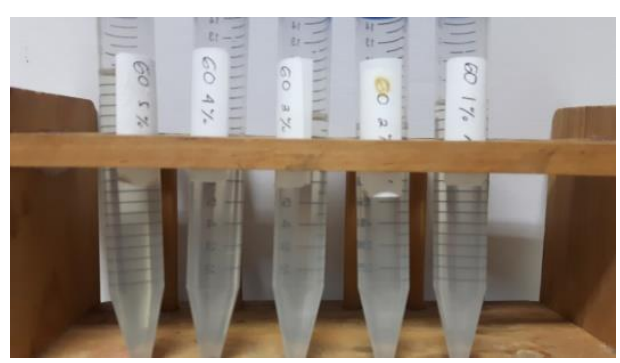

(a)

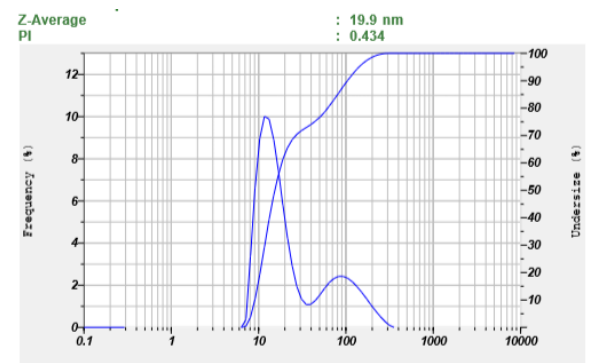

(b)

Gambar 2. Nanoemulsi minyak lengkuas yang terbentuk (a) dan analisis nanoemulsi dengan Particle Size Analyzer pada nanoemulsi minyak lengkuas $1 \%$
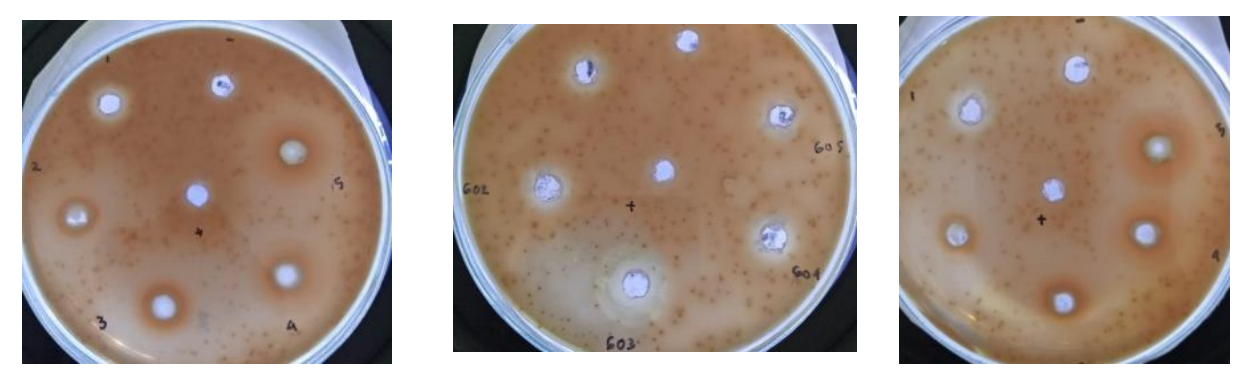

Gambar 3. Zona hambat nanoemulsi minyak lengkuas terhadap $H$. pylori

Tabel 4. Karakteristik Nanoemulsi minyak lengkuas dan zona hambat pada $H$. pylori

\begin{tabular}{cccc}
\hline $\begin{array}{c}\text { Sampel nanoemulsi } \\
\text { (NE) minyak } \\
\text { lengkuas }\end{array}$ & $\begin{array}{c}\text { Ukuran droplet nanoemulsi } \\
\text { yang terbentuk (nm) }\end{array}$ & $\begin{array}{c}\text { Persentase } \\
\text { transmitan (\%) }\end{array}$ & $\begin{array}{c}\text { Ukuran zona hambat } \\
\text { yang terbentuk (mm) }\end{array}$ \\
\hline NE 1\% & 19,9 & 99,089 & 9,5 \\
NE 2\% & 28,1 & 97,147 & 9,8 \\
NE 3\% & 30,4 & 96,353 & 10,1 \\
NE 4\% & 38,5 & 93,115 & 11,1 \\
NE 5\% & 47,9 & 91,110 & 10,0 \\
\hline
\end{tabular}

Minyak lengkuas memiliki mekanisme kerja dalam menghambat bakteri yang dikaitkan dengan toleransi intrinsik. Bakteri Gram negatif lebih sensitif terhadap minyak atsiri dibandingkan Gram positif. Hal ini berkaitan dengan tebal dan tipisnya lapisan dinding peptidoglikan pada masing-masing bakteri [22]. Pada Gambar 3 dan Tabel 4 menunjukkan bahwa nanoemulsi minyak lengkuas yang terbentuk mampu menghambat He. pylori dengan kadar hambat minimal (KHM) yaitu $1 \%$ dengan ukuran droplet 
terkecil 19,9 $\mathrm{nm}$ dan persentase transmitan atau tingkat kejernihan paling baik sebesar 99,089\% mampu menghambat bakteri dengan ukuran zona bening sebesar 9,5 mm. Selain senyawa yang terkandung dalam minyak lengkuas, zona hambat yang terbentuk pada bakteri uji juga berkaitan dengan penggunaaan jenis surfaktan. Penggunaan Tween 80 lebih baik dibandingkan dengan Tween 20. Tween 20 memiliki nilai HLB (HidrophylicLipophylic Balance) lebih tinggi dibandingkan Tween 80 yang mengakibatkan sifatnya lebih larut dalam air. Selain itu, surfaktan juga memengaruhi kelarutan senyawa antimikroba yang dalam hal ini minyak lengkuas yang memiliki sifat larut dalam minyak. Aktivitas nanoemulsi minyak lengkuas berhubungan dengan senyawa fitokimia yang terkandung di dalamnya. Senyawa antimikroba yang tertinggi yaitu methyl sinamat, zineol, dan alpha pinen. Senyawa metil sinamat dan pinen memiliki aktivitas antibakteri dengan mekanisme merusak membran bakteri yang bersifat selektif permeabel [14]. Sinergisme dan antagonisme senyawa fitokimia dalam minyak atsiri memengaruhi efek antibakteri atau sensitivitas bakteri.

Partikel nano droplet minyak lengkuas mampu mendorong bakteri untuk berdifusi sehingga memengaruh atraksi elektrostatik antara muatan positif pada minyak lengkuas dan muatan negatif pada bakteri yang dalam hal ini $H$. pylori. Fusi nanoemulsi dan $H$. pylori yang sangat kuat dapat mengeluarkan energi yang ada pada nanoemulsi. Senyawa aktif dalam nanoemulsi minyak lengkuas dan energi yang dilepaskan tersebut membuat membran bakteri yang bersifat permeabel menjadi tidak stabil sehingga sel menjadi lisis dan terjadi kematian sel bakteri [20]. Minyak lengkuas dipilih karena dapat digunakan secara peroral dan sediaan yang mampu membuat minyak ini cenderung lebih stabil yaitu membuatnya dalam bentuk nanoemulsi. Ukuran nano droplet yang digunakan memiliki permukaan yang lebih luas, stabil, lebih reaktif, dan cocok dalam penghantaran obat dalam tubuh [5]. Sehingga nanoemulsi minyak lengkuas diharapkan dapat menjadi kandidat untuk terapi melawan $H$. pylori penyebab infeksi lambung sehingga tidak berlanjut ke penyakit yang lebih serius seperti gastritis atrofi, metaplasia usus, dan noncardia gastric adenocarcinoma.

\section{KESIMPULAN}

Nanoemulsi minyak lengkuas (Alpinia galanga (L.) Willd) mampu menghambat pertumbuhan $H$. pylori dengan kadar hambat minimum $1 \%$ (ukuran droplet $19,9 \mathrm{~nm}$; persentase transmitan 99) dengan zona hambat sebesar 9,5 mm.

\section{UCAPAN TERIMA KASIH}

Penelitian ini didanai oleh Kementerian Ristek, Teknologi, dan Pendidikan Tinggi, Skema Penelitian Dosen Pemula dengan Perjanjian/ Kontrak Nomor 113/ SP2H/ LT/ DRPM/ 2019.

\section{DAFTAR PUSTAKA}

[1] Mabeku LBK, Ngama MLN, Leundji H (2018) Potential risk factors and prevalence of Helicobacter pylori infection among adult patients with dyspepsia symptoms in Cameroon. BMC Infectious Disease 18 (278): 1-11.

[2] Fock KM, Ang TL (2010) Epidemiology of Helicobacter pylori infection and gastric cancer in Asia. Journal Gastroenterol. Hepatol. 25: 479-486.

[3] Eusebi LH, Zagari RM, Bazzoli F (2014) Epidemiology of Helicobacter pylori infection. Helicobacter 19: 1-5

[4] Global Cancer Observation (2012) Indonesia: Estimated age-standardized incidence and mortality rates: both sexes.http://globocan.iarc.fr/Pages/fact_sh eets_population.aspx. Accessed: 25 December 2019.

[5] Parreira P, Soares BIG, Freire CSR, Silvestre AJD, Reis CA, Martins MCL, Duarte MF (2017) Eucalyptus spp. outer bark extracts inhibit Helicobacter pylori growth: In vitro studies. Industrial Crops and Products 105: 207-214.

[6] Clark JH, Deswarte FEJ (2008) The biofinery concept an integrated approach. Introduction to chemical from biomass. United Kindom, John Willey \&Sons, Ltd.

[7] Hsu Wei-Yea, Simonne A, Weissman A, Kim J (2010) Antimicrobial activity of greater galanga (Alpinia galanga [Linn.] Swartz] flowers. Food Science and Biotechnology 19 (4): 873-880.

[8] Khoerunnisa, U (2015) Studi farmakognosi rimpang dan uji aktivitas antimikroba minyak atsiri rimpang 
lengkuas (Alpinia galanga L.). Skripsi. Fakultas Farmasi, Universitas Airlangga.

[9] Yuharmen Y, Eryanti, Nurbalatif (2002) Uji aktifitas antimikroba minyak atsiri dan ekstrak metanol lengkuas (Alpinia galanga). Jurnal Nature Indonesia 12 (2): 223-227.

[10] Iravani S, Korbekandi H, Mirmohammadi SV, Zolfaghari B (2014) Synthesis of silver nanoparticles: Chemical, physical, and biological methods. Research in Pharmaceutical Sciences 9 (6): 385 - 406.

[11] Rossi GG, Guterres KB, Bonez PC, Gundel SS, Aggertt VA, Siqueira FS, Ourique AF, Wagnerd R, Klein B, Santoz RCV, Campos MMA (2017) Antibiofilm activity of nanoemulsions of Cymbopogon flexuosus against rapidly growing mycobacteria. Microbial Pathogenesis 113: 335-341.

[12] Quantrin PM, Verdi CM, de Souza ME, de Gogol SN, Klein B, Gundel A, Wagner $\mathrm{R}$, Vaucher RD, Ourique AF, Santos RCV (2017) Antimicrobial and antibiofilm activities of nanoemulsions containing Eucalyptus globulus oil against Pseudomonas aeruginosa and Candida spp. Microbial Pathogenesis 112: 230-242.

[13] Stteele W, Chirico RD, Cowell AB, Nguyen AJ (2002) Thermodynamic properties and ideal gas enthalpies of formation for trans-methyl cinnamate, alpha-methyl cinnamate, methyl methacrylate, 1-nonye trimethylacetic acid, trimethylacetic anhydride, and ethyl trimethyl acetate. Journal of Chemical and Engineering 47 (4): 700-714.

[14] Vita DD, Simonetti G, Pandolfi F, Costi R, Santo RD, D'Auria FD, Scipione L (2016) Exploring the anti-biofilm activity of cinnamic acid derivatives in Candida albicans. Bioorganic and Medicinal Chemistry Letters 26 (24): 5931-5935.

[15] Sumayani K, Rahayu, Yudi C (2008) Antibacterial activity of galangal rhizome juice in different concentration to the growth of Aeromonas hydrophila with in vitro method. Berkala Ilmiah Perikanan 3 (1): 83-87.

[16] Minarti AB, Ernawati $\mathrm{T}$ (2015) Bioaktivitas turunan metil sinamat terhadap pertumbuhan bakteri Escherichia coli, Staphylococcus aureus, Bacillus subtilis, Pseudomonas aeruginosa, dan Jamur Candida albicans. Jurnal Kimia Valensi: Jurnal Penelitian dan Pengembangan Ilmu Kimia 1 (1): 6064.

[17] Phanthongan $\quad P, \quad$ Lomaranta $P$, Chomawang Mt, Bunyapeapahtsar N (2013) Antibacterial activity of essential oil and their active components from Thai spices against foodborne pathogens. Science Asia 39: 472-476.

[18] Efruan GK, Martosupono M, Rondonuwo FS (2016) Review: Bioaktivitas senyawa 1,8 sineol pada minyak atsiri. Seminar Nasional Pendidikan dan Saintek (ISSN: 2557-533X).

[19] Silalahi, M (2017) Essential oil pada Alpinia galanga (L.) Willd dan pemanfaatanya. Jurnal Pro-Life 4 (1): 287-295.

[20] Lu WC, Da-Wei W, Chiun CR, ChingHua Y, Jen-Chieh T, Yu-Ting H, PoHsien L (2018) Preparation, characterization, and antimicrobial activity of nanoemulsions incorporating citral essential oil. Journal of food and Drug Analysis 26 (2): 82-89.

[21] Quatrin PM, Verdi CM, Ebling de Souza Má, Nunes de Godoi S, Klein B, Gundel A, Wagner R, de Almeida Vaucher R, Ourique AF, Vianna Santos RC (2017) Antimicrobial and antibiofilm activities of nanoemulsions containing Eucalyptus globulus oil against Pseudomonas aeruginosa and Candida spp. Microbial Pathogenesis

doi: 10.1016/j.micpath.2017.09.062.

[22] Bazargani MM, Jens R (2016) Antibiofilm activity of essential oils and plant extracts against Staphylococcus aureus and Escherichia coli biofilms. Food Control 61: 156-164. 